\title{
Study on the Influential Factors of the Involvement of Local People in Participatory Forest Management: The Case of Wof-Washa District, Ethiopia
}

\author{
Demissew Wondafrash Kura ${ }^{1,2^{*}} \quad{\text { Huajing } \mathrm{Li}^{1}}^{1}$ Di Shang $^{1}$ \\ 1.Forest Economics and Management, School of Economics and Management, Beijing Forestry University, \\ Beijing, China \\ 2.Ethiopian Environment and Forest Research Institute, P.O.BOX 2322, Addis Ababa, Ethiopia
}

\begin{abstract}
Participatory Forest Management (PFM) is crucial to the implementation of effective forest management and improvement in the living conditions of local communities. But local people involvement in PFM practice is affected by demographic, biophysical, institutional, and socio-economic factors. A cross-sectional survey research design was employed to collect information from 295 households (127 participants and 168 non-participants) by stratified sampling technique followed by a random sampling method. Both qualitative and quantitative data were collected from primary and secondary sources through structured interview schedules, Focused Group Discussion (FGD), Key Informant Interviews (KII) and field observation. The study employed both descriptive statistic and logistic regression model to compute the socio-economic characteristics and to identify influential factors that affect the community's involvement in PFM practice respectively. The results of the logistic regression model revealed that household's family size, educational status, training, benefits derived from the forest, and the number of livestock were positively affected local people's participation in PFM activities, whereas the distance of the forest from household resident was negatively affected. Apart from demographic, biophysical, institutional, and socio-economic factors granting ownership right, improved awareness, fear of displaced from the forest area, fear of forest lose and moral obligation were enhancing factors while the expansion of agricultural land and settlement, illegal logging, weak punishment, the insufficient fund or lack of incentives, poor forest management trend, conflict of interest, and doubt on the continuity of PFM program were some influential factors that hinder local people's participation in PFM activities. The study assisted policymakers to inform the influential factors that affect local people's participation in the study area and formulate effective policy advice to promote PFM practice in the region.
\end{abstract}

Keywords: Participatory forest management; Influential factors; Household; Socio-economics; Wof-Washa District; Policy advice

DOI: $10.7176 /$ RHSS/11-17-04

Publication date:September $30^{\text {th }} 2021$

\section{Introduction}

The forest resources in Ethiopia have been conserved by rules and regulations in the top-down approach system for a long time. But this kind of forest conservation practice has not been minimizing the problem of deforestation. As a result, forest resources in Ethiopia have been declining significantly in both size and quality. The total forest area decreased from 15.1 million ha in 1990 to 12.5 million ha in 2015, with an average annual decline rate of $0.8 \%$ (FRA, 2015). The decline of forest capacity at the global and national level is a great problem which now affects the livelihoods of people in different ways. According to Tesfaye et al. (2011), lack of awareness, negative attitudes, exclusion of local people in the economic benefit-sharing mechanism, lack of incentives, conflict of interest, weak legal actions are taken on illegal forest users, agricultural expansion, overgrazing, unspecified boundary and lack of skills and professional knowledge in the local community have exacerbated the loss of forests in Ethiopia.

To address the alarming rate of forest depletion, different forest conservation strategies are practiced. In many developing countries like Ethiopia, there has been a paradigm change in forest conservation and management plans from State-centered control towards community-based systems, with dual goals of fostering sustainable forest management and reducing poverty. Many studies stated that shifting forest management system from statemanaged top-down approach to people-centered bottom-up approach is effective and efficient method for the forest management practice (Gebreyohannes and Hailemariam, 2011). Among those forest conservation strategies, Participatory Forest Management (PFM) program is the key. It is a management system in which local forest users conserve the forest and improve the living status of their life (Ellen, 2010; Worah, 2008). This system enables the members to be the direct beneficiaries of the forests. In similar explanation, participatory forest management is a plan to achieve sustainable forest management by encouraging the local communities living in and around the forest by involving them in different forest conservation activities (Winberg, 2010). Due to the PFM program, planted forest area is going to increase from year to year because of the expansion of reforestation, afforestation and other forest rehabilitation and restoration strategies through community participation (Keenan et al., 2015). 
But local people involvement in PFM practice is affected by demographic factors (e.g. age, gender and, family size), biophysical factors (e.g. distance of local residents from the forest, and distance from the market), and socioeconomic factors (e.g. educational status, landholding size, income from the forest, alternative PFM incomegenerating activities and the number of livestock) (Tadesse et al., 2016). There are also different influential factors other than socio-economics, demographic, institutional, and biophysical factors that affect local community participation in PFM activities. These factors may enhance or inhibit the participation of local community's decision to involve in PFM activities. Incentives and ownership right are major factors that increase participation of household in PFM activities while expansion of agricultural land, illegal logging and conflict of interest inhibits local people involvement in PFM program (Degeti, 2003). Those factors have direct and indirect impact on both the local community livelihood's status and on the forest status (Abay, 2014).

Therefore, the purpose of this paper is to find out the factors that affect local people involvement in PFM activities in Wof-Washa district of North Shewa Administrative Zone of Ethiopia. The output of the study is essential for private, governmental, and non-governmental organizations which have close relation with community-centered forest conservation system. It can be used as a basis for upcoming researchers who have a strong desire to carry out research on related topics. The study also assisted policymakers to inform the influential factors that affect local people's participation in the study area and formulate effective policies to promote PFM in the region.

\section{Data and Methods}

\subsection{Description of the study area}

The study was conducted in Wof-Washa district of Tarmaber, North Shewa Zone, Amhara Region, Ethiopia. Tarmaber is located about $190 \mathrm{~km}$ north east of Addis Ababa, capital city of Ethiopia and $60 \mathrm{~km}$ from Debre Berhan town, the capital of North Shewa Zone. It is geographically located at latitude and longitude of $10^{\circ} 09^{\prime} 60.00^{\prime \prime} \mathrm{N}$ and $39^{\circ} 39^{\prime} 59.99^{\prime \prime} \mathrm{E}$ respectively. The district covers an area of 60925.6 ha. It has 19 rural subdistricts and 4 urban administrative towns. Wof-Washa district is the adjacent of Wof-Washa natural forest. This forest is Ethiopian oldest proclaimed state forest. Wof-Washa (literally meaning Bird's Cave) natural forest is called the 'lung' of the Amhara region because it is the last remnant of natural forest and is considered to be the most threatened forest ecosystem in the region.

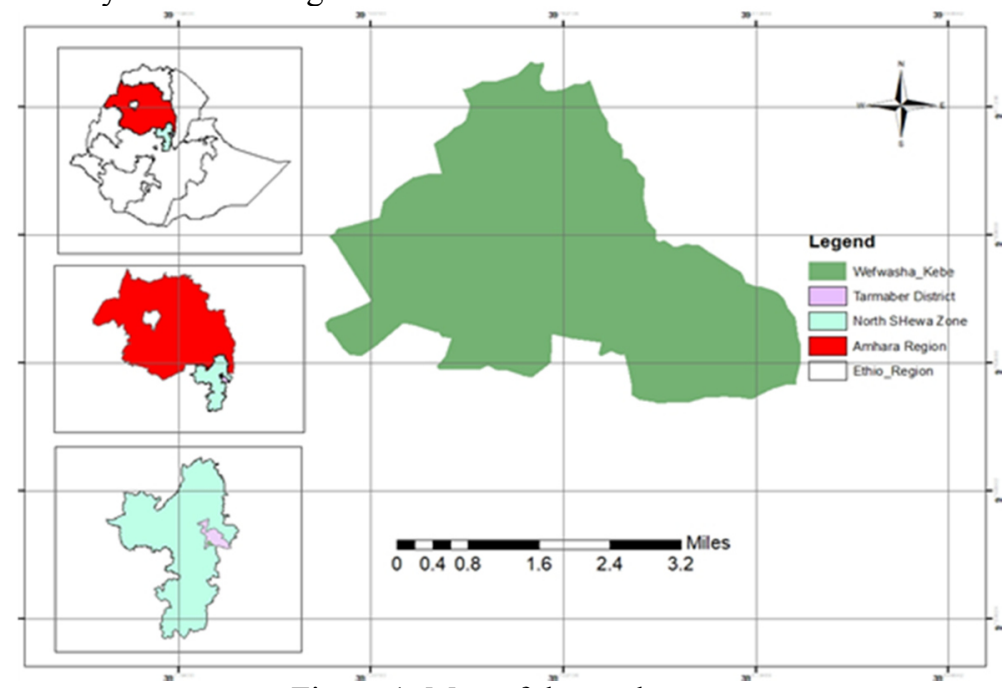

Figure 1. Map of the study area

\subsection{Data collection}

To conduct this research, the required sample of households was obtained from both PFM users and non-users group. Firstly, stratified sampling procedure was employed to select the number of samples from PFM users and non-users. To do so, Wof-Washa district was selected purposively. Secondly, 8 villages (Silase gedamna Tach gedam, Gureza debir, Mebirek Amba, Lankusona Giderach, Giftna awadi, Lay genet, Kebroyi and Chacha hudad) were randomly selected out of 18 villages. Then, the sample respondents were randomly drawn from the sampling frame using a simple random sampling method. Accordingly, the sample households from users and non-users were 127 and 168 respectively. Totally 295 households were selected to get the required data by using Yemane's formula of (1967) with 93\% confidence interval, and 7\% precision level as follows:

$$
\mathrm{n}=\frac{N}{1+N(e)^{2}}
$$

Where $\mathrm{n}$ - sample size, $\mathrm{N}$ - population size, and e - is the level of precision at $93 \%$ for PFM users and non- 
users at significance level 0.07 .

To conduct this research, both primary and secondary data were employed. Primary data were collected from the sampled households to identify demographic factors (age, gender, marital status, and family size), institutional factors (tenure security, local institutions, training and awareness, conflict of interest with non-PFM users), biophysical factors (distance from forest, distance from market), and socio-economic factors (benefits derived from forest, income-generating activities, educational status, number of livestock, and land holding size). Those primary data were collected by using the following data collection tools:

Household survey: The household survey questionnaire had both open and closed-ended questions and translated to the local language Amharic because of most of the local communities can't understand English. Openended questions were prepared to identify major influential factors that initiate (enhance) the local community to participate in PFM and major problems or factors that hinder (discourage) them not to involved in PFM activities.

Focus group discussion (FGD): In this study, the members of the focus group from both PFM users and non-user were represented from randomly selected villages.

Key informants interview (KII): The key informants were those experienced and knowledgeable households on PFM historical development. They know the local community's way of life before and after the introduction of PFM. The interview was adopted as a method for data collection partly due to its cost-effectiveness and its strength to get empirical data in both informal and formal settings. KII used in order to support the data, which collected from the household survey.

Field observation: In this study, besides the household survey, KII and FGD, direct field observation was also conducted to assess and evaluate major influential factors in and around Wof-Washa natural forest. This information was used to counter-check the information provided by household respondents, focus group participants and key informants.

\subsection{Methodology}

Both qualitative and quantitative data were analyzed by using descriptive statistics and econometric models respectively with the help of STATA software version 13. All data collected from the household interviews were coded and encoded on excel spread sheet.

Descriptive Statistics: The qualitative data obtained from the sampled household were analyzed using descriptive statistics like mean, percentage, frequency and summary statistics. The results were shown in the table under results and discussion part.

Logistic Regression Model: Quantitative data were analyzed by using logistic regression model. This econometric model is used to identify factors that affect local people involvement in PFM program. To explain the observed variation, the dependent variable which is local people participation is regressed as a function of the explanatory variables of demographic, biophysical, socio-economic and institutional factors following the methods used by (Gobeze et al, 2009). The logistic regression model ensures that the estimated response probabilities were strictly between zero and one. The response of the participants as to whether they participate in PFM can be outlined as a binary choice model, with an outcome (decision of households) decide to participate in PFM (coded 1) or did not participate in PFM (coded 0) or Simply put in the logistic model, Yi represents the dependent variable, participation, which equals to a household is coded 0 if a household member doesn't participate in participatory forest management activity and a household is coded 1 if any one of the household members participate in PFM activity.

Dependent variable $=$ Household's participation in PFM

$$
\left\{\begin{array}{l}
1=\text { participate } \\
0=\text { not participate }
\end{array}\right.
$$

Therefore, the probability of household participating $n-P F, \operatorname{Pr}\left(Y_{i}=1\right)$, is a joint probability density function/ likelihood function evaluated at $X_{i} \beta$, where $X_{i}$ is a host of explanatory variable and $\beta$ is coefficient of the predictor variable explaining the change in the dependent variable as a result of a unit change in an explanatory variable. The estimation from logistic transformation of the probability of participants' opinions in favor of participation in $\operatorname{PFM} \operatorname{Pr}\left(\mathrm{Y}_{\mathrm{i}}=1\right)$ can be represented as:

$\operatorname{pr}(\mathrm{yi}=1)=\frac{\exp (x i \beta)}{1+\exp (x i \beta)}$

The above equation can be reduced to:

$\operatorname{Pr}\left(Y_{i}=1\right)=\beta_{0}+\beta_{1} X_{1}+\beta_{2} X_{2}+\ldots+\beta_{i} X_{i}+\mu$

Where: ' $\mathrm{P}$ ' is the probability of presence of the characteristic of interest, community participation; ' $\beta$ ' is the coefficient of the predictor variables and is estimated from calibration data using maximum likelihood technique; ' $\beta_{\mathrm{i}}$ ' is vector parameters to be estimated; ' $\beta_{0}$ ' is the constant term; ' $\mu$ ' is the error term; ' $\mathrm{X}_{\mathrm{i}}$ ' is a host of explanatory variables.

The Model Equation: The model, which represents participation in PFM (coded 1) or did not participate in PFM (coded 0 ) and a host of explanatory variables, is given by:

$\mathrm{P}(\mathrm{PFM})=\beta_{0}+\beta_{1}(\mathrm{GENDHH})+\beta_{2}(\mathrm{AGEHH})+\beta_{3}(\mathrm{HHFSIZE})+\beta_{4}(\mathrm{EDUCHH})+\beta_{5}(\mathrm{TRAIHH})+\beta_{6}(\mathrm{DISFOR})+\beta_{7}(\mathrm{BE}$ 
$\mathrm{NDEF})+\beta_{8}(\mathrm{NUMBLI})+\mu$

Where $\beta_{0}=$ the constant term; $\mu=$ Error term; $\beta_{1}-\beta_{8}=$ Parameters measure the change in household participation; $\mathrm{P}(\mathrm{PFM})=$ Households participation in PFM; GENDHH= Gender of household; AGEHH = Age of household in years; HHFSIZE = Household family size in persons; EDUCHH= Educational status of household in schooling years; TRAIHH= Availability of training for households; DISFOR= Distance from forest to household resident in $\mathrm{km}$; DISMARK $=$ Distance from market in $\mathrm{km}$; LANHSIZ $=$ Land holding size in hectare; BENDEF=Benefits derived from forest; NUMBLI= Number of livestock

Table 1 Description of the variables and their expected sign

\begin{tabular}{|c|c|c|c|}
\hline Variables Description & $\begin{array}{l}\text { Variables } \\
\text { Code }\end{array}$ & $\begin{array}{l}\text { Characteristic of } \\
\text { Variables }\end{array}$ & $\begin{array}{l}\text { Expected Effects on } \\
\text { Participation }\end{array}$ \\
\hline Participatory forest management & PFM & Dummy & Dependent variable \\
\hline $\begin{array}{l}\text { Gender of the household } \\
0 \text {-Female, 1-Male }\end{array}$ & GENDHH & Dummy & $+/-$ ve \\
\hline Age of the household in Year & AGEHH & Continuous & $+/-$ ve \\
\hline Households' Schooling year & EDUCHH & Continuous & $+\mathrm{ve}$ \\
\hline Number of household members & HHFSIZE & Continuous & + ve \\
\hline $\begin{array}{l}\text { Distance of the forest from the } \\
\text { household's home in } \mathrm{km}\end{array}$ & DISFOR & Continuous & - ve \\
\hline Benefit derived from WWF & BENDEF & Dummy & $+\mathrm{ve}$ \\
\hline $\begin{array}{l}\text { Training and awareness about PFM } \\
0 \text { - haven't access, } 1 \text { - have access }\end{array}$ & TRAIHH & Dummy & + ve \\
\hline Number of livestock & NUMBLIV & Continuous & $+\mathrm{ve}$ \\
\hline
\end{tabular}

\section{Results and Discussion}

3.1 Household's socioeconomics characteristics

Table 2 Summary of descriptive statistics for dummy explanatory variables

\begin{tabular}{llllllll}
\hline Variables & & \multicolumn{2}{c}{ Total (295) } & \multicolumn{2}{c}{ Participants (127) } & \multicolumn{2}{c}{ Non-participants (168) } \\
& & $\mathbf{N}$ & $\mathbf{\%}$ & $\mathbf{N}$ & $\mathbf{\%}$ & $\mathbf{N}$ & $\mathbf{\%}$ \\
\hline GENDHH & Male & 229 & 77.6 & 105 & 82.7 & 124 & 73.81 \\
& Female & 66 & 22.4 & 22 & 17.3 & 44 & 26.19 \\
TRAIHH & Have access & 169 & 57.3 & 117 & 92.1 & 52 & 30.95 \\
& Haven't access & 126 & 42.7 & 10 & 7.87 & 116 & 69.05 \\
BENDEF & Benefited & 168 & 56.9 & 123 & 96.85 & 45 & 26.79 \\
& Not benefited & 127 & 43.1 & 4 & 3.15 & 123 & 73.21 \\
P(PFM) & Participant & 127 & 43.1 & 127 & 100 & 0 & 0 \\
& Non-participant & 168 & 56.9 & 0 & 0 & 168 & 100 \\
\hline
\end{tabular}

Descriptive Statistics: According to the dummy explanatory variables described in table 1, the survey result which obtained from the total household, 229(77.6\%) of the respondents' gender were male-headed households, and the rest 66(22.4\%) were female-headed. Among the total sampled male household headed, 105(82.7\%) of them were participant and 124(73.81\%) were non-participant in PFM. And also from the total sampled femaleheaded households, 22(17.3\%) of them were participant while 44(26.49\%) of them were non-participant. $117(92.1 \%)$ of participants got training about forest management and different PFM income generating activities while 10(7.87) of them haven't access to get training but they were effective to get benefit from forest and interested to participate in different PFM activities. Beside 52(30.95\%) of non-participants have the opportunity to get training they were not successful. On the other hand 116(69.05) of non-participants haven't get the opportunity to take training. $123(96.85 \%)$ of participant household got direct physical benefit from wof-washa forest while $4(3.15 \%)$ of them haven't get direct benefit from wof-washa natural forest but they got indirect benefits from different PFM income generating activities.

Table 3 Summary of descriptive statistics for continuous explanatory variables

\begin{tabular}{lllllllllll}
\hline Variables & \multicolumn{2}{c}{ Total $(\mathbf{N}=\mathbf{2 9 5})$} & \multicolumn{2}{c}{ Participants $(\mathbf{N}=127)$} & \multicolumn{4}{c}{ Non-participants (N=168) } \\
& Mean & SD & Mean & SD & Min & Max & Mean & SD & Min & Max \\
\hline AGEHH & 48.67 & 11.73 & 47.32 & 11.14 & 28 & 82 & 49.69 & 12.09 & 28 & 83 \\
EDUCHH & 2.84 & 2.92 & 3.78 & 3.27 & 0 & 10 & 2.12 & 2.39 & 0 & 10 \\
HHFSIZE & 5.35 & 2.11 & 6.46 & 2.29 & 2 & 13 & 4.51 & 1.49 & 2 & 13 \\
DISFOR & 5.49 & 2.51 & 3.14 & 1.17 & 0 & 5 & 7.26 & 1.65 & 0 & 11.5 \\
NUMBLI & 3.01 & 1.63 & 3.76 & 1.83 & 0 & 8.6 & 2.44 & 1.19 & 0 & 8.6 \\
DISMARK & 22.14 & 2.53 & 21.57 & 2.52 & 15.5 & 27 & 22.57 & 2.46 & 15.5 & 28 \\
LANHSIZ & 1.3 & 0.76 & 0.9 & 0.51 & 0 & 2 & 1.63 & 0.77 & 0 & 3 \\
\hline
\end{tabular}


The mean age of the participant household headed was 48.67 year with a range of 28 to 82 years old. While the mean age of non-participant household headed was 49.69 years with a range of 28 to 83 years. The average family size of participant household was 5 persons with 2 and 13 persons minimum and maximum respectively whereas the average family size of non-participant household was 5 to 13 persons with 2 and 13 persons minimum and maximum respectively. The average educational level of participant household-headed was 2.84 years with 0 and 10 years minimum and maximum schooling years while the non- participant household-headed average educational level was 2.12 years with 0 and 10 years minimum and maximum schooling years respectively. The average distance from forest was $3.14 \mathrm{~km}$ with a range of 0 to $5 \mathrm{~km}$ in case of participants but in case of nonparticipants the average distance was $7.26 \mathrm{~km}$ with a range of 0 to $11.5 \mathrm{~km}$. The average number of livestock for participants was 3.76TLU with 0 and 8.6 TLU minimum and maximum respectively whereas the average livestock in TLU for non-participants was 2.44 with 0 and 8.6 minimum and maximum respectively. The mean distance from market to participant's resident was $21.57 \mathrm{~km}$ with a range of 15.5 to $27 \mathrm{~km}$ while the mean distance from market to non-participants resident was $22.57 \mathrm{~km}$ with a range of 15.5 to $28 \mathrm{~km}$ minimum and maximum respectively. The average land holding size of participant households was 0.9 ha with 0 and 2 ha minimum and maximum respectively whereas the average land holding size of non-participant household was 1.63 ha with a range of 0 to 3 ha minimum and maximum respectively.

Table 4 Binary logistic regression result

\begin{tabular}{lllllll}
\hline PPFM & Coef. & Odds Ratio & Std. Err. & $\mathbf{z}$ & $\mathbf{P}>|\mathbf{z}|$ & $\mathbf{d y} / \mathbf{d x}$ \\
\hline GENDHH & -1.88 & 0.15 & 2.00 & -0.93 & 0.35 & -0.02 \\
AGEHH & 0.00 & 1.00 & 0.08 & 0.04 & 0.97 & 0.00 \\
HHFSIZE & $2.22^{* * *}$ & 9.23 & 0.85 & 2.6 & 0.00 & 0.03 \\
EDUCHH & $0.90^{* * *}$ & 2.45 & 0.34 & 2.65 & 0.00 & 0.01 \\
TRAIHH & $4.97^{* * *}$ & 143.33 & 1.61 & 3.07 & 0.00 & 0.06 \\
DISFOR & $-4.28^{* * *}$ & 0.01 & 1.37 & -3.11 & 0.00 & -0.05 \\
BENDEF & $6.91^{* *}$ & 1008.05 & 3.04 & 2.27 & 0.02 & 0.08 \\
NUMBLIV & $1.43^{* *}$ & 4.17 & 0.64 & 2.22 & 0.02 & 0.02 \\
cons & -5.85 & 0.00 & 4.66 & -1.26 & 0.21 & \\
\hline
\end{tabular}

Note: $* *$ and $* * *$ show variables significant at $5 \%$ and $1 \%$ significance level respectively; Number of obs $=295$; LR chi $^{2}(8)=380.47$; Prob $>$ chi $^{2}=0.0000 ;$ Pseudo $\mathrm{R}^{2}=0.9435$; Log likelihood = -11.386377.

Marginal effect for logistic regression $(d y / d x)$ : The marginal effect of each independent variable on the dependent variable was not constant but it depends on the value of the independent variables. Thus, marginal effects can be a means for generalizing how conversion in response was associated to change in a covariate. For continuous independent variables, the marginal effect measures the instantaneous rate of change (derivative) that is when calculated them for a variable while all other variables were held constant which means in this study change in the probability participatory forest management with a unit change in the continuous independent variable. Thus, it is not possible to conclude the estimated parameters as the effect of the independent variable upon participatory forest management. However, it is possible to compute the marginal effects at some interesting values of the significant explanatory variables.

Household's family sizes: It was positively associated with participation in PFM and statistically significance at $1 \%$ level. It was found that households who have one more person family member had a higher probability of participation in PFM by a factor of 2.22 with households having one lesser person of a family member. The marginal effect value of the variable was 0.03 . This shows that as the number of family size increased by one person, the probability of participation of the household in PFM increased by $2.53 \%$.

It is most likely that large family members have a greater demand for forest products such as firewood, grass, seed wild fruits, and other basic needs from different income-generating activities. But a small number of family sizes unable to participate due to workload. This result is supported by Ogada (2012), of those households with large family sizes have more labor energy to dedicate to PFM activities. Moreover, such households would be better placed in terms of labor for extraction of forest products from forest and to involve in different incomegenerating PFM activities.

Educational status: Educational status has a positive association with participation in PFM activities and statistically significant at a $1 \%$ level. The coefficient indicated that a year increase in education results in the participation of a household in PFM increases by a factor of 0.90 to households who have one lesser year of education. The marginal effect value of the educational status was 0.01 . This indicates that as schooling year increased by one year, the probability of participation of the household in PFM activities increased by $1.02 \%$. This result showed that households who had a better educational status were more likely to participate in PFM activities. This was probably due to the fact that households with formal education can obtain information about forest benefits easily compared to non-educated households. This finding is also supported by Faham et al.(2008), which stated that the willingness of forest users' participation in forest management activities increases as their level of formal education increases. 
Training and Awareness: As hypothesized, access to different training and experience sharing has significant positive influence on the likelihood of deciding on participation in the forest management activities. The training was positively associated and significant at $1 \%$ level with Participation.

The coefficient for the variable in the model was 4.97. The marginal effect value of training and awareness was 0.06 . This implies that households with better training and experience sharing about forest management were more likely to participate in PFM activities unlike those households with no training or awareness about forest conservation. Or the result of this variable can be interpreted to mean an increase in the proportion of training to total household participation in PFM by $1 \%$ increases the possibility of household's participation by 5.65\%. Thus, when there were training and experience sharing the better trained of a household about PFM for both management of the forest and income generating activities for the local community was increased by 5.65\%. Studies in Darghouth et al. (2008), and Maraga et al. (2010) identified the existence of synergies between the local people's participation and their awareness of natural resources-related problems. Furthermore, Teshoma (2010) indicted that awareness of the aim of management can affect the level of participation.

Distance home from the forest: Home distance from the forest is another biophysical influential factor in the household decision to participate in PFM or not. As predicted earlier in the hypothesis of this study, distance from the forest has related negatively with the level of participation in PFM activities at 1\% significant level. The coefficient for the variable in the model was -4.28 . The marginal effect value of the variable was -0.05 . As I was expected the finding of this research showed that holding other variables on their mean values, distance home from Wof-Washa natural forest increase by $1 \mathrm{~km}$, the probability participating in PFM decreased by about 4.86\%. This was because as a household further away from the forest resource, the less they interact with forest which probably led them to associate fewer values with the forest. Households join in community forest to get benefits from the extraction of forest products, and households that are far from forests will have less motivation to join because it would be more expensive for them to travel to the forests when they consider transportation cost and energy what they lose.

Benefit derived from the wof-washa forest: Physical benefit derived from the forest was positively associated and significant at 5\% level with Participation in PFM activities. The finding of this study showed that holding other variables on their mean values, then when benefit derived from the forest increased by $1 \%$ probability leads participation in forest management would be increased by $7.86 \%$. It can be interpreted to mean that when households assess their benefit from the forest and more useful for livelihoods, their probability to participate in PFM increased by $7.86 \%$. This can be stated as a high level of forest dependency leads to greater participation in forest management. Higher economic benefits from forests encourage the community to participate in the management of forest resources.

Number of livestock owned by household headed: Number of livestock in TLU is positively correlated with participating in PFM and statistically significant at 10\% level. For each additional unit of livestock heads, the likelihood of participating in PFM activities increases by a factor of 1.42 . The marginal effect value of the variable was 0.02 . This indicates that as livestock ownership increased by one TLU, the probability of PFM participation of the household increased by $1.62 \%$. There is similar study which stated that livestock size has a positive relation with participation of forest management practice (Musyoki et al.,2013; Oli and Treue, 2015).

\subsection{Enhancing factors}

There are many influential factors that enhance local people's participation in participatory forest management. These enhancing factors are identified in the field survey by using open-ended questionnaires. The participant respondents have listed-out some of the most important variables that enhanced their participation. Funding of incentives, granting ownership right, fear of displaced from the forest area, fear of forest loose and moral obligations are major factors that increase participation of household in PFM activities 


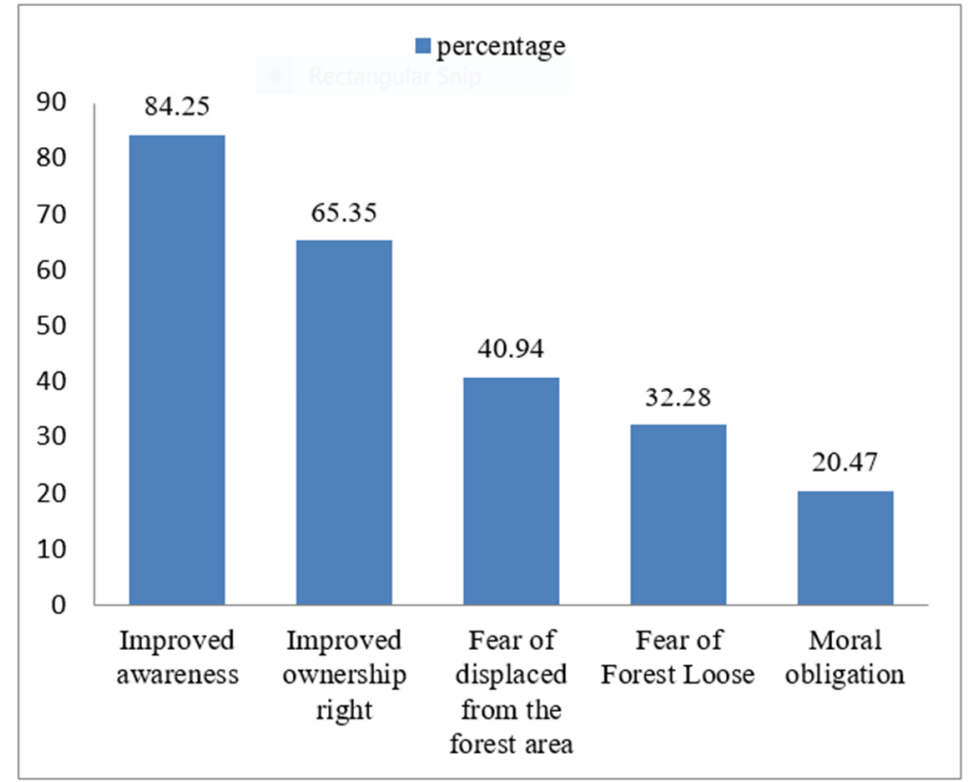

Figure 2. Major factors that enhance local people involvement in PFM

Improved awareness: When the sampled PFM user respondents were asked what factors initiate them to participate in PFM activities, 107(84.25\%) of them expressed that understanding the importance of forest and the effect of the destruction were the major factors that encouraged them to participate in PFM actively. Almost all of the respondents agreed that the forest has paramount importance for them. When they were asked whether they know or not about the adverse effect of deforestation, they know it very well. This is equivalent to having a better understanding or grasping basic knowledge about the physical, social, and economic impact of deforestation, people to take part in forest conservation activities.

Improved ownership right: According to 83 PFM users (65.35\%) of respondents granted the ownership right on forest resource enhanced their participation in PFM activities. This implies that people have the right to use each resource, taking it as their own possession. If there is no rule and regulation that ensure people the right to use, they will have the intention of over utilization and or wasteful utilization for only temporary benefit. Giving the right to use the forest has played a great role in developing a sense of ownership right so that they feel much concern towards the forest development.

Fear of displaced from the forest area: The PFM user groups were established with those people who are living in and around Wof-Washa natural forest. So those people are supporting their life directly or indirectly from the forest. They graze their cattle, they plough near the forest, and they use the forest product like fuelwood and other forest products for their own consumption as well as for commercial purpose. Figure 2 indicates that 52 respondents (40.94\%) mentioned fear of displacement can be considered as one factor that motivates them in forest management activities.

According to some key informants and project staffs, one of the major factors that speed up the registration of PFM users was fear of such displacement. Some respondents explained that the beginning of the PFM user establishment in the study area, they were in suspected of some bad outcomes. They had neither confidence nor belief in the realization of the project. Some respondents stated that, they are highly adapted with that forest for the survival of their cattle and their children and they have fear of displacement from the forest. Then they were registered to the membership.

Fear of forest loose: Some respondents explained that, they do not like to see the high deforestation; they would rather like to see green and improved forest. They have bad feeling toward destruction of forest resource. Accordingly, 41 respondents (32.28\%) explained that they have lived within the forest for a longer period of time starting from their grandfathers. So they have greatly concerned about the forest but they do not have power to save it from destruction. According to them their active participation emanates from the love they have for the forest. This shows living in and around the forest for a long period of time in their family chains contributed to initiate them to conserve the forest for the coming generation.

Moral obligation: Moral obligation is an important motivating factor in forest conservation activity. As it is indicated above, 26 respondents i.e., 20.47 percent claimed that they have positive attitude towards PFM because they feel accountable to it. The most important parts in initiating people to PFM are awareness about the advantage of the existing forest and disadvantage of its destruction. 


\subsection{Hindering factors}

There are many factors that could inhibit local people's motivation towards the conservation of forest in their surrounding in addition to socio-economic, institutional, biophysical and demographic factors. Those factors have direct and indirect impact on both the local community life status and on the forest status (Abay, 2014). According to the non-participant respondents, expansion of agricultural land and settlement, insufficient fund to support PFM activities, poor management and lack of incentive, conflict of interest with non-user groups, and inequity of benefit sharing and population growth were major factors that hinder their participation in participatory forest management.

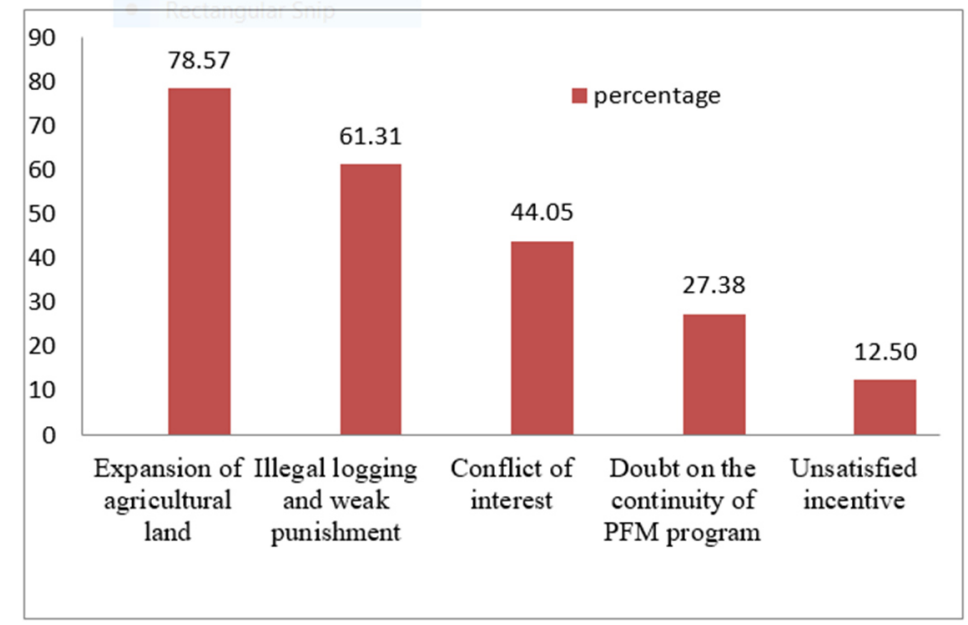

Figure 3. Major factors that hinder local people involvement in PFM

Expansion of agricultural land and settlement: The lack of granted land tenure or forest user rights was the main reason why local households don't promise themselves to participate actively in forest management practice. From the total non-user local households, 132(78.57\%) of them stated that expansion of agricultural land in the district inhibit them from actively participate in PFM activities.

Illegal logging and weak punishment: Out of the total non-user respondents in the survey, 103 respondents (61.31\%) stated some other factors like absence of supporting by district administration. This shows the absence of measures on illegally clearing of forest. They referred to the district administrators, police and court's failure to take appropriate action on individuals to be blamed or accused to the damage of the forest. According to some informants, the policy, law and regulation that enforce to take an action on illegal users and traders were very weak. For example, the punishment taken on illegal users by the district court is 500ETB. The PFM user groups complain for the court to make some correction on those illegally beneficiaries. But still there is less cooperative effort by police and court in taking appropriate action on this illegal action. Those illegal activities and weak punishment trend in the district hinder the local community and participate less in PFM activities.

Conflict of interest: Conflicts often arise because people have different utilization experience on natural resources such as forests. The cause of conflict was the residents of Wof-Washa district PFM user groups needed to use the forest in restricted and sustainable way but the neighboring sub-districts residents need to use the forest as free access. But those people of other villages want to get additional benefit from Wof-Washa natural forest. Due to this reason there might be conflict of interest.

According to the non-participant respondent and key informants in the study area, 74(44.05\%) of them mentioned that conflict of interest with participant groups makes them discouraged from participating in PFM. Conflict results not only detain the participation of the community but also famine, susceptibility and immigration are often exaggerated (Tedla, 2007). Conflict affects both bio-physical resource and local people's willingness to involve in PFM activities.

Doubt on the realization and continuity of PFM program: According to the open-ended questioners result, some respondents have suspected on the realization and life span of the project in the study area. 46 non-user respondents mentioned that having suspect was one hindering factor in the PFM project. According to them, the project may phase-out so that all the effort applied come without any result. As the conductor of the study observed, the communities were not sure the forest is their own property if the project does not exist. Two respondents suspected that, the government enforces to have limited farmland and house that we have outside the forest and this could inhibit us from participating in the program. The major issues that lessen the confidence of community on the approach lie on absence of granting ownership right at policy level. If people are assured to the property right on forest, no matter the project exist or phase-out, they are likely to protect the forest as their own personal possessions.

Unsatisfied incentive: Local communities should gain incentives as per their contribution to forest 
conservation efforts. There were $21(12.5 \%)$ respondents who explained that lack of incentives is one factor that hinders their participation in participatory forest management. Some of the informants correlated the incentives with the salary that they gain from patrolling the forest. They briefly explained that as far as they look after the forest day and night, they got an unsatisfied salary. In addition to this, currently, the forest is transferred from Amhara forest enterprise to Tarmaber district land and natural resource management office. During this transition period, the guards complain that they didn't get their monthly salary for the last 3 consecutive months. This clearly showed that, unsatisfied salary or fewer incentives leads less participation trend in forest conservation program.

\section{Conclusion and Recommendations \\ 4.1 Conclusion}

Local people's Participation in PFM practice is affected by demographic, biophysical, institutional, and socioeconomic factors. These influential factors may enhance (encourage) or inhibit (discourage) the involvement of the local communities in participatory forest management program. This survey was conducted in Wof-Washa district by using 127 PFM user and 168 non-user sample respondents. The influential factors had identified and computed to what extent they affect the local household's decision to involve in PFM activities. As a result, demographic factors (age, gender, family size), biophysical factors (distance from forest, and distance from the market), and socio-economic influential factors (educational status, landholding size, income from the forest, alternative PFM income-generating activities and the number of livestock) were identified and measured their influence on local community's decision to participate in PFM activities by using both descriptive and logistic regression analysis method.

The logistic regression model result revealed that household family size, educational status, training, number of livestock, and economic benefit derived from Wof-Washa forest have positive association with the local community's participation. The distance of the forest from the household's residence is negatively related and decreased the likelihood of participation in PFM activities at less than $1 \%$ significant level. The other variables such as age and gender were not significantly associated with the local community's participation in PFM. Therefore, we can conclude that household decision of participation in PFM is influenced by family size, educational status, training, the distance of the forest from home, livestock holding size and physical benefits derived from the forest.

The result of the study also showed that granting ownership right, improved awareness, fear of displaced from the forest area, fear of forest lose and moral obligation were encouraged or enhanced the participation practice of households in PFM activities while the expansion of agricultural land and settlement, illegal logging, weak punishment, the insufficient fund to support PFM activities, poor management and lack of incentives, conflict of interest with non-user groups, and doubt on the continuity of PFM program were some hindrance factors. Therefore, appropriate punishment, awareness creation, strong policy implementation, clearly discussion with the neighboring district community, timely providing the compensation, and NGOs initiation households to participate in PFM activities were basic elements to promote PFM practice in the region.

\subsection{Policy recommendations}

This paper addressed the constraints that prevailed or motivate local community's involvement in participatory forest management activities. Therefore, based on the results of the study and future implication, the following recommendations were given for the concerned body.

The government policy framework on PFM should be revised and incorporate the socioeconomic, demographic, institutional, and biophysical factors which were highly significant in the study area. These variables if they are carefully incorporated in policy formulation, they could promote local people's participation in PFM. And they are important to combat the listed major problems in the study area (e.g. legal actions should be taken on illegal forest users, there should be a strong policy that protects the forest from damage).

The distance of forest from home has a negative impact on participation due to information asymmetry, time delay, and fewer direct benefits obtained from the forest. Therefore, the improvement of rural infrastructures such as road and transportation should be improved in the study area to promote household's participation in different forest conservation activities. Part of the management fund could be allocated to construct the road.

An extensive capacity-building and empowerment program should be implemented by the district land and natural resource management office to increase the household's participation. The PFM strategy would be a feasible measure that could restructure the problem of forest destruction. Forest management should effective if the local people involved in planning, idea-generating, protection of regenerating trees, re-planting trees, decision making, monitoring, and evaluation activities based on their interest.

The number of livestock owned by households has a substantial role in PFM practice. Therefore, improving the production and productivity of livestock through providing veterinary services, strengthening milk-producing and delivering group, providing training and awareness in cooperatives and individual manner, and providing fodder resources from the forest as an incentive is important to promote community's participation in PFM 
program at the study area.

Local communities should plant a tree, particularly outside the forest so as to establish their own woodlots, which can reduce the deforestation pressure on natural forests. The gap between demand and supply for firewood, construction material, and furniture is increasing from time to time. Finding alternative sources of energy should be considered in the study area. For example; using local innovative methods like biogas and wood saving stoves should be adopted in the district in order to minimize the local community forest dependency trend.

Developing the forest for nature-based tourism purposes will help to create a business in the future. Ecotourism practice helps to improve and diversify the incomes of the local people through creating job opportunities, such as hiking trails and interpretive materials including field guides to birds, endemic wild animals, tourist guiding services and indigenous woody species would be valuable assets for practicing community-based eco-tourism in the study area. And also local people can get benefits from horse renting.

To conserve the forest and to confirm continued forest life in the long run, there should be strong local community participation in PFM program and positive association of local community with the forests. For the better accomplishment of the PFM program, it needs to consistent encouragement of local community. This should be achieved by increasing incentives, increasing access to invite potential sponsors, promoting the formation of social groups, and improving infrastructures.

\section{Acknowledgments}

We would like to thank Tarmaber district administration office for providing secondary data and consistent help during the field data collection. The field data collection processes would have been impossible without the efforts of Kinfe, Debebe, Beletew, Tizibt, Wondimu and Zewudnesh. We would like to express our deeper gratitude to them and the residents of wof-washa district sampled households. And also we would like to extend our gratitude to Mr. Dagnachew.

\section{References}

Abay, T., 2014. Factors Affecting Forest User's Participation in Participatory Forest Management; Evidence from Alamata Community Forest, Tigray; Ethiopia (Doctoral dissertation).

Darghouth, S., Ward, C., Gambarelli, G., Styger, E. and Roux, J., 2008. Watershed management approaches, policies, and operations: lessons for scaling up.

Degeti, T., 2003. Factors affecting people's participation in participatory forest management: The case of IFMP Adaba-Dodola in Bale zone of Oromia Region (Doctoral dissertation, Addis Ababa University).

Ellen, W., 2010. Participatory forest management in Ethiopia: Practices and experiences. Food and Agriculture Organization Sub Regional Office for Eastern Africa, Addis Ababa.

Faham, E., Rezvanfar, A. and Shamekhi, T., 2008. Analysis of socio-economic factors influencing forest dwellers' participation in reforestation and development of forest areas (The case study of West Mazandaran, Iran). American Journal of Agricultural and Biological Science.

FRA, F., 2015. Global forest resources assessment 2015 Desk reference. Food and agriculture organization of the United Nations, Rome.

Gebreyohannes, G. \& Hailemariam, G., 2011. Challenges, opportunities and available good practices related to zero grazing in Tigray and Hararghe, Ethiopia. Drylands Coordination Group (DCG) Report, (66).

Gobeze, T., Bekele, M., Lemenih, M. and Kassa, H., 2009. Participatory forest management and its impacts on livelihoods and forest status: the case of Bonga forest in Ethiopia. International forestry review, 11(3), pp.346358.

Keenan, R.J., Reams, G.A., Achard, F., de Freitas, J.V., Grainger, A. and Lindquist, E., 2015. Dynamics of global forest area: Results from the FAO Global Forest Resources Assessment 2015. Forest Ecology and Management, 352, pp.9-20.

Maraga, J.N., Kibwage, J.K. and Oindo, B.O., 2010. Factors determining community participation in afforestation projects in River Nyando basin, Kenya. African journal of environmental science and technology, 4(12), pp.853-859.

Musyoki, Josephine Kamene, Jayne Mugwe, Kennedy Mutundu, and Mbae Muchiri. "Factors influencing level of participation of community forest associations in management forests in Kenya." Journal of Sustainable Forestry 35, no. 3 (2016): 205-216.

Ogada, M.J., 2012. Forest management decentralization in Kenya: effects on household farm forestry decisions in Kakamega: International Livestock Research Institute, Selected paper prepared for presentation at the International Association of Agricultu.

Oli, B.N. and Treue, T., 2015. Determinants of participation in Community Forestry in Nepal. International Forestry Review, 17(3), pp.311-325.

Tadesse, S., Woldetsadik, M. and Senbeta, F., 2016. Impacts of participatory forest management on forest conditions: evidences from Gebradima Forest, southwest Ethiopia. Journal of Sustainable Forestry, 35(8), 
pp.604-622.

Tedla, S., 2007. Environment and natural resources as a core asset in wealth creation, poverty reduction, and sustainable development in Ethiopia. International Union for the Conservation of Nature (IUCN).

Tesfaye, Y., Roos, A., Campbell, B.M. and Bohlin, F., 2011. Livelihood strategies and the role of forest income in participatory-managed forests of Dodola area in the bale highlands, southern Ethiopia. Forest policy and economics, 13(4), pp.258-265.

Teshoma, A.J., 2010. Determinating factors for a succesful establishment of participatory forest management: a comparative study of Goba and Dello districts, Ethiopia (Master's thesis, Universitetet i Agder, University of Agder).

Winberg, E., 2010. Participatory Forest Management in Ethiopia, practices and Experiences Forestry Volunteer Food and Agriculture Organization Sub Regional Office for Eastern Africa (SFE), Addis Ababa. Food and Agriculture Organization Sub Regional Office for Eastern Africa (SFE), Addis Ababa.

Worah, S., 2008. Participatory Management of Forests \& Protected Areas: A Trainer's Manual. Regional Community Forestry Training Center for Asia and thePacific.

Yamane, T., 1967. Problems to accompany" Statistics, an introductory analysis". Harper \& Row. 